\title{
HISTOMORPHOLOGICAL ANALYSIS OF MIXED BAG OF MEDIASTINAL LESIONS IN A TERTIARY CARE CENTRE
}

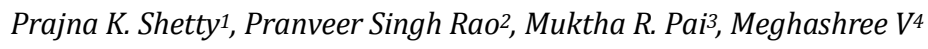

1 Postgraduate Student, Department of Pathology, A. J. Institute of Medical Sciences and Research Centre, Mangalore, Karnataka. ${ }^{2}$ Assistant Professor, Department of Pathology, Ananta Institute of Medical Sciences and Research Centre, Rajasamand, Rajasthan. 3Professor and HOD, Department of Pathology, A. J. Institute of Medical Sciences and Research Centre, Mangalore, Karnataka. ${ }^{4}$ Postgraduate Student, Department of Pathology, A. J. Institute of Medical Sciences and Research Centre, Mangalore, Karnataka.

\section{ABSTRACT}

\section{BACKGROUND}

Mediastinum is a Pandora's box consisting of variety of non-neoplastic and neoplastic lesions, which present as masses.

Aims and Objectives- The purpose of this study is to emphasise the role of CT-guided Tru-Cut biopsy in early diagnosis of mediastinal lesions.

\section{MATERIALS AND METHODS}

This was a retrospective descriptive study of the histopathological spectrum of the primary mediastinal lesions in a tertiary care hospital between January 2011 and May 2015. Relevant clinical and radiological details were obtained for each case. Histological examination of the true-cut biopsies and resected specimens was carried out followed by immunohistochemistry for confirmation whenever necessary.

\section{RESULTS}

Of the 32 cases included in the present study, nineteen cases showed lesions in the anterior, five in the posterior and eight in the middle mediastinum. Most of these patients were in the $2^{\text {nd }}$ decade of life with male preponderance. All these mediastinal lesions were categorised into benign (46.9\%), malignant (43.75\%) and inflammatory (9.37\%), of which the most common malignant lesion was lymphoma (37.5\%) followed by thymoma (28.13\%) and germ cell tumour (6.25\%). Tuberculosis (6.25\%) was the commonest inflammatory lesion. The most common lymphoma was nodular sclerosis Hodgkin lymphoma (58.33\%) and among the thymomas, it was type AB thymoma (44.44\%). Thymic tuberculosis, extragonadal thymic germinoma and mediastinal immature teratoma with vascular proliferation were the rare lesions included in this study. The sensitivity and specificity of this study were $72.72 \%$ and $75 \%$ respectively.

\section{CONCLUSION}

The CT-guided Tru-Cut biopsy is an early diagnostic tool in the evaluation of various mediastinal lesions.

\section{KEYWORDS}

Primary Mediastinal Tumours, Thymic Mass, Mediastinal Lymphoma, Thymoma, Thymic Germinoma, Thymic Tuberculosis, TruCut Biopsy of Mediastinal Lesions.

HOW TO CITE THIS ARTICLE: Shetty PK, Rao PS, Pai MR, et al. Histomorphological analysis of mixed bag of mediastinal lesions in a tertiary care centre. J. Evolution Med. Dent. Sci. 2018;7(16):1978-1983, DOI: 10.14260/jemds/2018/445

\section{BACKGROUND}

The mediastinum is a Pandora's box which occupies the thoracic cavity between the pleural cavities with the lungs laterally, sternum anteriorly, the vertebral column posteriorly and from the thoracic inlet down to the diaphragm.(1) It has been divided into four compartments, i.e. superior, anterior, middle and posterior. It is a site affected by a wide variety of pathological processes including nonneoplastic and neoplastic lesions, benign and malignant, primary and metastatic, many of which present as mediastinal masses. Anterior mediastinal tumours account for $50 \%$ of all mediastinal masses including thymoma, teratoma and lymphoma.(2)

'Financial or Other Competing Interest': None.

Submission 07-03-2018, Peer Review 02-04-2018,

Acceptance 09-04-2018, Published 16-04-2018.

Corresponding Author:

Dr. Prajna K. Shetty,

AL-25, NITK Campus, Srinivasnagar,

Surathkal-575025, Mangalore (D. K.)

Karnataka, India.

E-mail: prajnashettyk@gmail.com

DOI: $10.14260 /$ jemds $/ 2018 / 445$

\section{Aims and Objectives}

1. The purpose of this study was to evaluate our institutional experience of histological spectrum of primary mediastinal lesions.

2. To emphasise the role of CT-guided Tru-Cut biopsy in early diagnosis of mediastinal lesions.

\section{MATERIALS AND METHODS}

This was a retrospective descriptive study of 32 patients, who had undergone tru-cut biopsy, resection and both for mediastinal lesions from January 2011 to May 2015 in a tertiary care hospital. Tissue was fixed in $10 \%$ buffered formalin and processed by paraffin embedding. The histopathology sections obtained were stained with routine Haematoxylin and Eosin stains. Immunohistochemical (IHC) panel of lymphoma and neuroendocrine tumours were applied for confirmation in some cases. Relevant clinical information that included age and gender of the patients and compartment location of the lesions was recorded for all cases. 


\section{RESULTS}

A total of 32 cases of mediastinal masses, confirmed by CT imaging included 14 tru-cut biopsies, 7 resected specimens and 11 both tru-cut and resection specimens (Figure 1). The age range affected by the mediastinal tumours were 2 months to 77 years of age (mean age of 36.5 years). The male-tofemale ratio was 7:3. Anterior mediastinal lesions were more common (Figure 2). The commonest mediastinal neoplasms were lymphoma (37.5\%) followed by thymoma $(28.13 \%)$ and germ cell tumours (6.25\%). Thymic tuberculosis $(6.25 \%)$ was a common inflammatory lesion. Other cases included in the study are listed in Table 1.

Among the mediastinal lymphomas, Hodgkin Lymphoma (HL) exclusively including Nodular Sclerosis HL (NSHL) constituted about $58.33 \%$ cases, whereas Non-Hodgkin Lymphoma (NHL) accounted to only about $44.67 \%$ cases (Table 2) including Precursor T-cell Lymphoblastic lymphoma (pre-T LBL) and diffuse large B-cell lymphoma (DLBCL). NSHL showed male preponderance. Age group ranged from 15 - 29 years with a mean age of 22 years. Histopathology sections of these lymph nodes showed lacunar cells and diagnostic Reed Sternberg (RS) cells with extensive area of sclerosis. IHC performed in 5 cases showed Golgi and membranous positivity for CD15 and CD30, which confirmed the diagnosis (Figure 3).

One of the cases of pre-T LBL was observed in a 17-yearold male where the lymph node architecture was completely replaced by large neoplastic cells with high $\mathrm{N}$ : C ratio, convoluted nuclei with membrane folding, delicate chromatin, small nucleoli and scant cytoplasm with the starry sky pattern, diffuse and single file pattern of perinodal infiltration along with high mitotic rate. IHC markers such as CD3, CD99 and TDT positivity confirmed the diagnosis of pre$\mathrm{T}$ LBL. Another case of Pre-LBL was morphologically confused with B1 thymoma, but was finally confirmed by negativity of cytokeratin.

Among the older age group DLBCL was more common $(16.67 \%)$ and showed diffuse sheets lymphoma cells had large non-cleaved with round-to-oval vesicular to hyperchromatic nuclei, small nucleoli and scant cytoplasm. IHC markers done for the confirmation of non-germinal centre DLBCL were positive for CD20, MUM-1, BCL-6 and negative for CD10.

According to WHO classification of thymomas, 2 cases of type A, 4 cases of type AB, 2 cases of type $B 1$ and one case of type B2-B3 thymoma were noted. One out of these cases showed transcapsular invasion and other with mediastinal fat and pericardium (Figure 4).

A 72 years female with an anterior mediastinal mass morphologically displayed organoid clusters, ribbons, festoons and sheets of polygonal tumour cells having pleomorphic oval nuclei, fine chromatin indistinct nucleoli and eosinophilic granular cytoplasm. The differential diagnosis of thymic paraganglioma and metastatic carcinoma from the lung were ruled out by the positivity for CK7 and negativity for TTF-1 respectively. Hence, diagnosis of thymic atypical carcinoid was considered with the positivity for synaptophysin and chromogranin along with CK7 positivity (Figure 5).

Two cases $(6.45 \%)$ constituted germ cell tumours, which included one case of primary thymic germinoma and immature teratoma each respectively. The extragonadal thymic germinoma was noted in the middle mediastinum of a 23-year-old female without any ovarian pathology and normal levels of serum AFP, B-hCG. It had microscopic picture of seminoma and was confirmed by the positivity of epithelial marker CD117 and negativity for CK7. Another case was of immature cystic teratoma in a 5-year-old baby, which showed vascular proliferation with endothelial cells within the glial tissue (Figure 6).

There was a case of 14-year-old female who presented with cough, right-sided neck swelling and matted cervical lymph nodes. The FNAC of the enlarged lymph node confirmed the diagnosis of tuberculosis and was treated with antitubercular drugs. But after 5 months when she presented with breathlessness, a chest x-ray showed a mediastinal mass. This lesion was excised and microscopic examination revealed the thymic tissue with Hassall's corpuscles and large foci of tuberculosis with dispersed foci of dystrophic calcification, haemorrhage surrounded by reactive lymphoid tissue (Figure 7).

\begin{tabular}{|c|c|c|c|c|c|c|c|c|c|}
\hline Diagnosis & \begin{tabular}{|c|}
$0-$ \\
9
\end{tabular} & $\begin{array}{l}10- \\
19\end{array}$ & $\begin{array}{l}20- \\
29\end{array}$ & $\begin{array}{l}30- \\
39\end{array}$ & $\begin{array}{l}40- \\
49\end{array}$ & $\begin{array}{c}50- \\
59\end{array}$ & \begin{tabular}{|c|}
$60-$ \\
69
\end{tabular} & $\begin{array}{l}70- \\
79\end{array}$ & Total \\
\hline Thymoma & & & 1 & & & 5 & 2 & 1 & 9 \\
\hline Lymphoma & 1 & 2 & 5 & 1 & & 2 & 1 & & 12 \\
\hline Tuberculosis & & 1 & & & & & 1 & & 2 \\
\hline $\begin{array}{l}\text { Inflammatory } \\
\text { myofibroblastic } \\
\text { tumour }\end{array}$ & & & 1 & & & & & & 1 \\
\hline $\begin{array}{l}\text { Calcifying fibrous } \\
\text { pseudotumour }\end{array}$ & & & & 1 & & & & & 1 \\
\hline Germ cell tumour & 1 & & 1 & & & & & & 2 \\
\hline $\begin{array}{c}\text { Infected } \\
\text { pericardial cyst }\end{array}$ & 1 & & & & & & & & 1 \\
\hline Lipoma & & & 1 & & & & & & 1 \\
\hline Lymphangioma & & & & 1 & & & & & 1 \\
\hline $\begin{array}{c}\text { Thymic atypical } \\
\text { carcinoid }\end{array}$ & & & & & & & & 1 & 1 \\
\hline Schwannoma & & & & & 1 & & & & 1 \\
\hline Total & 3 & 3 & 9 & 3 & 2 & 7 & 4 & $\mathbf{1}$ & 32 \\
\hline Table 1. Distr & & tion & $f \mathrm{Vo}$ & & $T$ & & & & \\
\hline
\end{tabular}

\begin{tabular}{|c|c|}
\hline Type of Lymphoma & No. of Cases (\%) \\
\hline Nodular Sclerosis Hodgkin Lymphoma & $7(58.33 \%)$ \\
\hline $\begin{array}{c}\text { Precursor T-cell lymphoblastic } \\
\text { lymphoma }\end{array}$ & $3(25.0 \%)$ \\
\hline Diffuse large B-cell lymphoma & $2(16.67 \%)$ \\
\hline \multicolumn{2}{|c|}{$\begin{array}{c}\text { Table 2. Incidence of Various Types of Lymphomas in the } \\
\text { Mediastinum }\end{array}$} \\
\hline
\end{tabular}

\begin{tabular}{|c|c|c|c|c|}
\hline Study & $\begin{array}{c}\text { Present } \\
\text { Study }\end{array}$ & $\begin{array}{c}\text { Karki } \\
\text { et al }\end{array}$ & $\begin{array}{c}\text { Dubashi } \\
\text { et al4 }\end{array}$ & $\begin{array}{c}\text { Bhageri } \\
\text { et al 5 }\end{array}$ \\
\hline $\begin{array}{c}\text { Anterior } \\
\text { mediastinum }\end{array}$ & 59 & 70.3 & 93.6 & 69.5 \\
\hline $\begin{array}{c}\text { Middle } \\
\text { mediastinum }\end{array}$ & 25 & 3.8 & 0 & 10.5 \\
\hline $\begin{array}{c}\text { Posterior } \\
\text { mediastinum }\end{array}$ & 16 & 25.9 & 6.4 & 20 \\
\hline
\end{tabular}

Table 3. Comparison of Distribution of Mediastinal Lesions in Various Studies according to Location 


\begin{tabular}{|c|c|c|c|c|c|}
\hline Study & $\begin{array}{c}\text { Present } \\
\text { Study }\end{array}$ & $\begin{array}{c}\text { Sharma } \\
\text { et al1 }\end{array}$ & $\begin{array}{c}\text { Karki } \\
\text { et al }^{3}\end{array}$ & $\begin{array}{c}\text { Aroor } \\
\text { et al }^{4}\end{array}$ & $\begin{array}{c}\text { Aggarwal } \\
\text { et al }^{5}\end{array}$ \\
\hline Benign & $40.7 \%$ & $73.33 \%$ & $66.6 \%$ & $68.57 \%$ & $34.5 \%$ \\
\hline Malignant & $45.15 \%$ & $26.67 \%$ & $26 \%$ & $31.43 \%$ & $27.6 \%$ \\
\hline Table 4. Comparison of Distribution of Malignant and \\
Benign Lesions in various Studies \\
\hline
\end{tabular}

\begin{tabular}{|c|c|c|c|c|}
\hline Study & $\begin{array}{c}\text { Temes } \\
\text { et al[6] } \\
\text { (1999) }\end{array}$ & $\begin{array}{c}\text { Shrivastava, } \\
\text { et al[7] } \\
\text { (2006) }\end{array}$ & $\begin{array}{c}\text { Dubashi, } \\
\text { et al[8] } \\
\text { (2009) }\end{array}$ & $\begin{array}{c}\text { Present } \\
\text { Study } \\
\text { (2017) }\end{array}$ \\
\hline $\begin{array}{c}\text { Lymphoma } \\
\text { (\%) }\end{array}$ & 55 & 29 & 30.6 & 38.7 \\
\hline HL (\%) & 18 & 24 & 6.5 & 58.33 \\
\hline NHL (\%) & 37 & 5 & 24.1 & 41.67 \\
\hline
\end{tabular}

Table 5. Comparison of Distribution of various Types of Lymphomas in the Mediastinum

\begin{tabular}{|c|c|c|c|c|c|}
\hline Study & $\begin{array}{c}\text { Present } \\
\text { Study }\end{array}$ & $\begin{array}{c}\text { Karki } \\
\text { et al }^{\mathbf{3}}\end{array}$ & $\begin{array}{c}\text { Dubashi } \\
\text { et al }^{\mathbf{8}}\end{array}$ & $\begin{array}{c}\text { Baram } \\
\text { et al }\end{array}$ & $\begin{array}{c}\text { Shamsuddin } \\
\text { et al 10 }^{\mathbf{1 0}}\end{array}$ \\
\hline Thymoma & $29.3 \%$ & $80 \%$ & 30.76 & $28.57 \%$ & $22.7 \%$ \\
\hline $\begin{array}{c}\text { Age } \\
\text { Group } \\
\text { (years) }\end{array}$ & $50-69$ & $40-59$ & $36-64$ & $48-75$ & $22-65$ \\
\hline \multicolumn{7}{|c|}{ Table 6. Incidence of Thymoma in various Age Groups } \\
\hline
\end{tabular}

Diagnosis

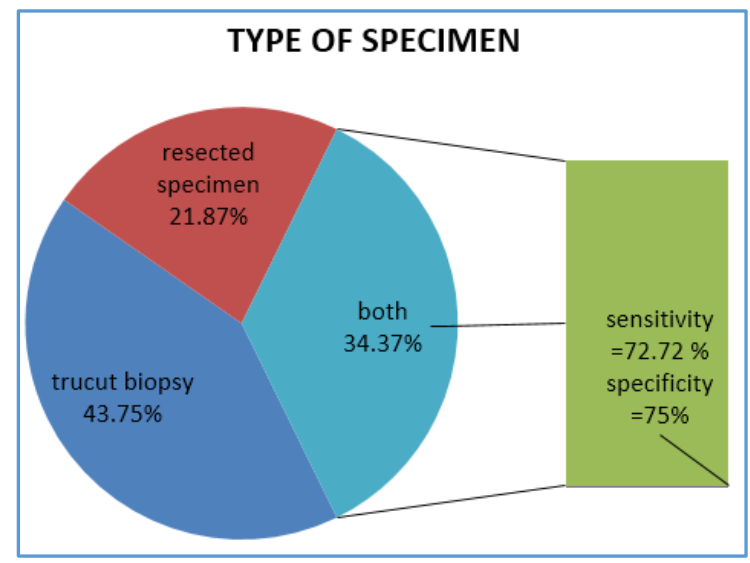

Figure 1. Type of Specimen

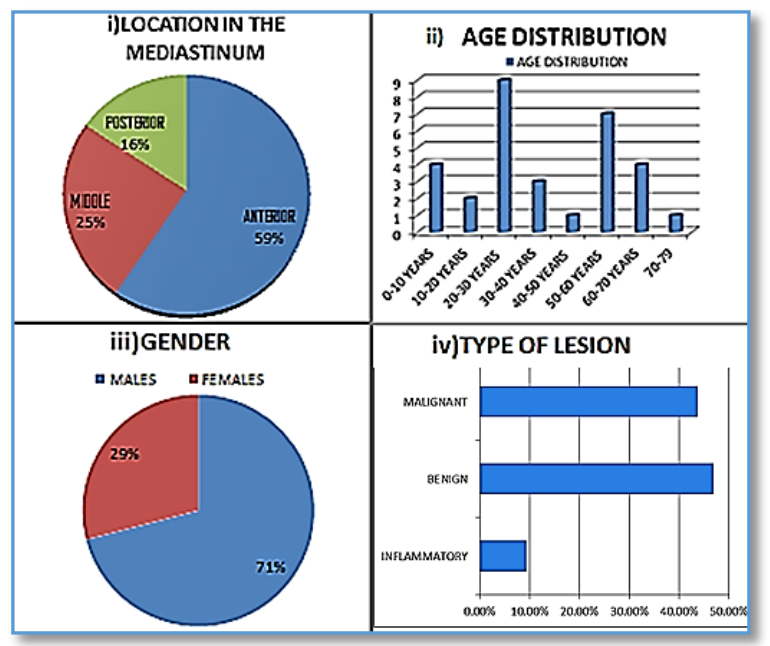

Figure 2. Incidence of Mediastinal Lesion according to i) Location, ii) Age, iii) Gender and iv) Type of Lesion

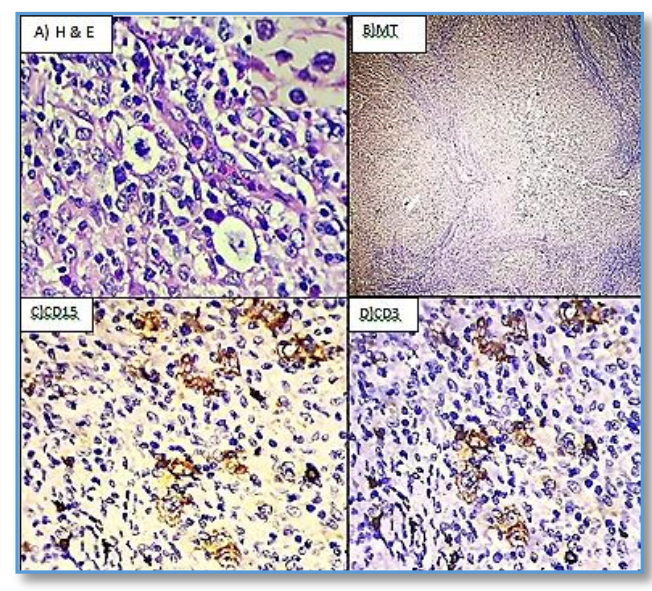

Figure 3. NSHL- A: Neoplastic RS Cells and Mitotic Figure within Lacunar Cell (H and Ex1000). B: Increased Bands of Sclerosis around the Nodules (Masson Trichrome x40). IHC Markers- C, D: CD15 and CD45-Positive in RS Cells

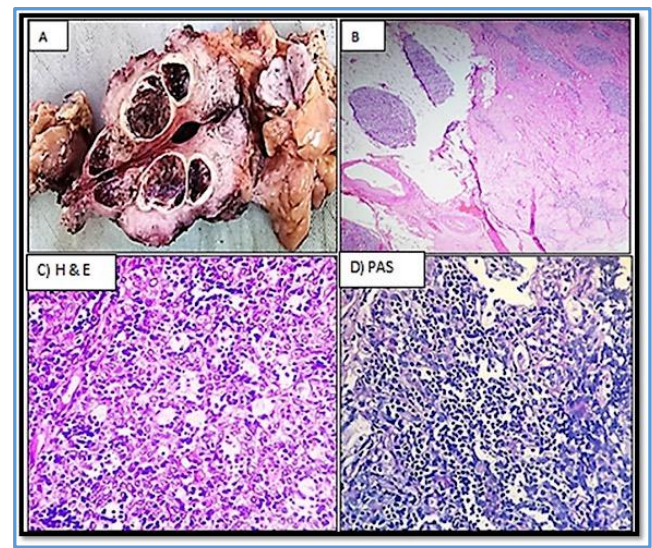

Figure 4. Thymoma (B2, B3)- A: Thymectomy Specimen m/s $8 \times 6 \times 2.8 \mathrm{~cm}$ with Grey-Brown Tumour Separated into Nodules by $g / w$ Fibrous Septae. B: Pericapsular

Infiltration of the Tumour into the Mediastinal Fat (Modified Masaoka Stage III) C: Neoplastic Tumour Cells are Polygonal in morphology having Open Nuclear Chromatic and Prominent Nucleoli admixed with few Nuclei having coarse Chromatin and scant Cytoplasm. D: PAS positive Proteinaceous Material in the Perivascular Space and Lymphocytic Infiltrate are Noted

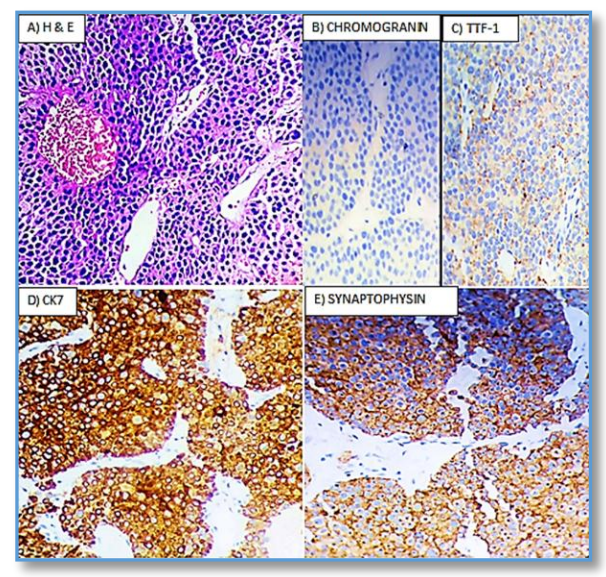

Figure 5. Thymic Atypical Carcinoid. A: Neoplastic Polygonal Tumour Cells with Pleomorphic Nuclei and Eosinophilic Granular Cytoplasm arranged in Organoid Clusters and Sheets. IHC-B, C: Chromogranin and TTF-1negative in Tumour Cells. D, E: CK7 and Synaptophysinpositive in Tumour Cells 


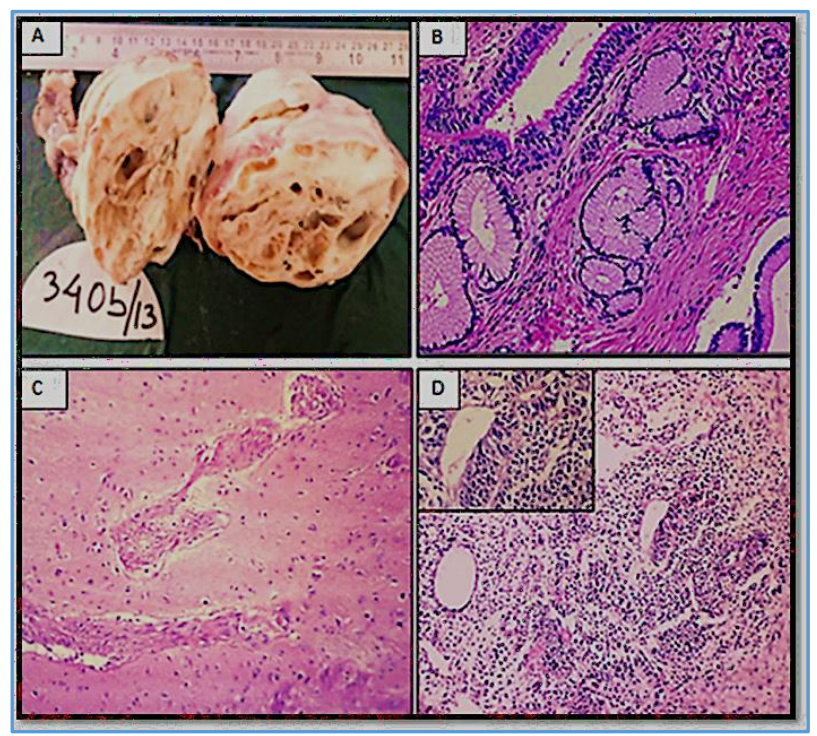

Figure 6. Immature Teratoma m/s $16 \times 12 \times 6.5 \mathrm{~cm}$ weighing 550 gms. A: Cut Surface-variegated with Solid and Cystic Areas. B: Mature Endodermal Elements like Mucinous Glands and Respiratory Epithelium. C: Proliferating Capillaries within the Glial Tissue. D. Immature Neuroectoderm forming Rosettes and Tubules

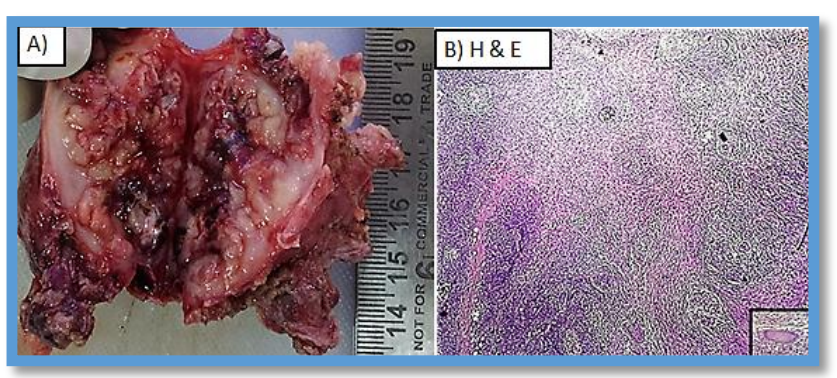

Figure 7. Thymic Tuberculosis. A. Thymectomy Specimen m/s $9 \times 3.5 \times 1.5$ cm, Cut Surface shows Cystic Spaces Rimmed by Fibrous Capsule and containing Whitish Granular Material. B. Thymic Tissue showing Extensive Fibrosis, Necrosis, Studded with Caseating and NonCaseating Granulomas (H and $E x 100)$ with Langhan's Giant Cell (Inset)

\section{DISCUSSION}

Primary mediastinal tumours are uncommon and represent about $3 \%$ of the tumours within the chest wall. Most of the tumours were anterior mediastinal masses as in the present study and other studies (Table 3).3,8,11 According to Aroor et al and Aggarwal et al, these lesions were mainly noted in the third decade. ${ }^{4,5}$ Whereas most of the cases were in the sixth decade in the present study. Male preponderance was noted in all the cases including the present study. Benign lesions were higher in number in all the studies (Table 4).1,3,4,5

In the present series, lymphomas formed the predominant group constituting $37.5 \%$ of mediastinal lesions followed by thymoma (28.13\%), which was comparable with the other studies (Table 5) (Table 6).

Zubair et al described an incidence of $32 \%$ mediastinal involvement by NSHL. ${ }^{12}$ In the present study the incidence of NSHL was $58.33 \%$ (Table 2), which was confirmed by IHC. Mediastinal involvement was noted in 3 cases of pre-LBL, which was in concordance with the study by Nathwani et al ${ }^{13}$ and positivity for IHC markers like CD99 and TDT confirmed the diagnosis in the present study as well as the study by Maitra et al. ${ }^{14}$

According to Dasgupta et al, thymoma was more common between the age group of 30 to 56 years. ${ }^{15}$ The present study showed a wide range of age of its incidence between 25 to 75 years. The most common variant of thymoma was $\mathrm{AB}$ subtype followed by B1 subtype in the present series and study by Sharma et al. ${ }^{1}$ The lymphocyte rich thymoma (B1 subtype) could be misdiagnosed as lymphoma. ${ }^{16}$ Similarly, in the present study we encountered diagnostic dilemma in the diagnosis of one of the cases of B1 subtype, because of lymphoid rich background. Later, it was confirmed by subsequent biopsy. Thymomas though indolent their behaviour cannot be predicted based on its histology, because it may invade locally and give rise to implants or metastasise. ${ }^{17,18}$ Masaoka system of staging has been widely used as it takes into account the local extension of the tumour. ${ }^{2}$ In the present study one case of type A and type B2B3 each presented with stage IIa and stage III respectively.

Germ cell tumours constituted $6.25 \%$ of cases in the present study which was discordant when compared with the observations of Aroor et al and Dasgupta et al.1,15 Mature glial tissue with bordered proliferating capillaries is a feature of malignant glial tumour in the brain, but it can be seen in the mature teratoma in the mediastinum. ${ }^{19}$ In the present study, a 4-year-old male child presenting with an immature mediastinal teratoma had the combination of mature glial tissue rimmed by proliferating vascular proliferation with adjacent foci of an immature neuroepithelial component.

In the literature, primary mediastinal seminoma was first described by Woolner et al.20 Chan et al had first reported a primary thymic seminoma in a 32-year-old female. ${ }^{21}$ According to Iczkowski et al, CD117 (C-kit) was equivalently superior to PLAP in the diagnosis of extragonadal germ cell tumour (especially seminoma). ${ }^{22}$ Thus, in the present study with the normal levels of serum AFP and B-hCG, the CD117 positive extragonadal germinoma was proved to be of thymic origin because of the negativity for CK. ${ }^{21}$

In the literature, only few case reports have been mentioned about the thymic tuberculosis. ${ }^{23-37}$ In the present study, we had thymic tuberculosis in a 10-year-old seronegative female child.

Pericardial cysts are the congenital cysts formed due to the failure of one of multiple disconnected lacunae to merge with others. These are more common in third or fourth decade of life. ${ }^{38}$ In the present study, we had an infected pericardial cyst in a 10-month-old male baby.

The present study has $75 \%$ specificity and $72.7 \%$ sensitivity, which is comparable with the study by Aggarwal et al.

\section{CONCLUSION}

Mediastinum is a complex anatomic area playing host to a wide range of neoplastic and non-neoplastic lesions. The most common malignant tumour was lymphoma and benign tumour was thymoma with Tru-Cut biopsy being diagnostic in most of the cases. This study emphasises the role of CTguided Tru-Cut biopsy in early exact diagnosis of mediastinal lesions with adequate sampling and least risk surgical complications. It is also a strong determinant for the treatment options ranging from medication and surgery to irradiation and chemotherapy. 
The availability of small amount of data regarding the mediastinal lesions, the present study highlights the rarity yet diversity in morphology of these lesions.

\section{REFERENCES}

[1] Sharma P, Jha V, Kumar N, et al. Clinicopathological analysis of mediastinal masses: a mixed bag of nonneoplastic and neoplastic etiologies. Turk Patoloji Derg 2017;33(1):37-46.

[2] Juanpere $S$, Canete $\mathrm{N}$, Ortuno $\mathrm{P}$, et al. A diagnostic approach to the mediastinal masses. Insights imaging 2013;4(1):29-52.

[3] Karki S, Chalise S. Analysis of mediastinal lesions: a study of 27 cases. J of Patholology of Nepal 2011;1(2):114-7.

[4] Aroor AR, Prakasha SR, Seshadri S, et al. A study of clinical characteristics of mediastinal mass. J Clin Disgn Res 2014;8(2):77-80.

[5] Aggarwal R, Rao S, Chopra P, et al. Morphological spectrum of mediastinal lesions with special emphasis on evaluation of needle biopsy: an experience from a tertiary care hospital. Indian J Med Res 2016;144(4):544-51.

[6] Temes R, Chavez T, Mapel D, et al. Primary mediastinal malignancies: findings in 219 patients. West J Med 1999;170(3):161-6.

[7] Shrivastava CP, Devgarha S, Ahlawat V. Mediastinal tumors: a clinicopathological analysis. Asian Cardiovasc Thorac Ann 2006;14(2):102-4.

[8] Dubashi B, Cyriac S, Tenali SG. Clinicopathological analysis and outcome of primary mediastinal malignancies - a report of 91 cases from a single institute. Ann Thorac Med 2009;4(3):140-2.

[9] Baram A, Tayeb ZA. Mediastinal masses: retrospective single center based study. J Cancer \& Sci Ther 2016;8(10):252-6.

[10] Shamsuddin F, Khadilkar UN, Saha D, et al. A clinicopathologic study of mediastinal lesions with special emphasis on thymomas. IJRMS 2015;3(8):1902-10.

[11] Bagheri R, Afghani R, Haghi SZ, et al. Evaluation of 95 cases with mediastinal tumors. J Cardio-Thorac Med 2015;3(1):249-53.

[12] Zubair H, Muktha PR, Chakraborti S, et al. Distribution of nodal lymphomas in a referral hospital of Mangalore city. Indian J Cancer 2015;52(4):557-61.

[13] Nathwani BN, Kim H, Rappaport H. Malignant lymphoma, lymphoblastic. Cancer 1976;38(2):964-83.

[14] Maitra A, McKenna RW, Weinberg AG, et al. Precursor B-cell lymphoblastic lymphoma. A study of nine cases lacking blood and bone marrow involvement and review of literature. Am J Clin Pathol 2001;115(6):868-75.

[15] Dasgupta S, Bose D, Bhattacharyya NK, et al. A clinicopathological study of mediastinal masses operated in a tertiary care hospital in Eastern India in 3 years with special reference to thymoma. Indian J Pathol Microbiol 2016;59(1):20-4.

[16] Dueñas PV, Sánchez TI, Río GF, et al. Usefulness CTguided F.N.A.C. in the diagnosis of mediastinal lesions. Arch Bronconeumol 2010;46(5):223-9.
[17] Salyer WR, Eggleston JC. Thymoma: a clinical and pathological study of 65 cases. Cancer 1976;37(1):229-49.

[18] Moran CA, Suster S. On the histologic heterogeneity of thymic epithelial neoplasms. Impact of sampling in subtyping and classification of thymomas. Am J Clin Pathol 2000;114(5):760-6.

[19] Akbulut M, Zekioglu 0, Terek MC, et al. Florid vascular proliferation in mature cystic teratoma of the ovary: case report and review of the literature. J of Tumori 2009;95(1):104-7.

[20] Woolner LB, Jamplis RW, Kirklin JW. Seminoma (germinoma) apparently primary in the anterior mediastinum. N Engl J Med 1955;252(16):653-7.

[21] Chen ZG, Pan HX, Wang T, et al. Primary thymic seminoma in a 32-year-old female. Ann Oncol 2010;21(5):1132-4.

[22] Iczkowski KA, Butler SL, Shanks JH, et al. Trials of new germ cell immunohistochemical stains in 93 extragonadal and metastatic germ cell tumors. Hum Pathol 2008;39(2):275-81.

[23] Peabody JW, Walkup HE, Murphy JD. Tuberculoma of the mediastinum: report of the first culturally proved case. J Thorac Surg 1958;35(3):397-9.

[24] Duprez A, Cordier R, Schmitz P. Tuberculoma of the thymus. First case of surgical excision. J Thorac Cardiovasc Surg 1962;44:115-20.

[25] Silvola HJ, Lahdesmaki M. On tuberculosis of the thymus. Ann Chir Gynaecol Fenn 1966;55(1):27-30.

[26] FitzGerald JM, Mayo JR, Miller RR, et al. Tuberculosis of the thymus. Chest 1992;102(5):1604-05.

[27] Simmers TA, Jie C, Sie MC. Thymic tuberculosis: a case report. Neth J Med 1997;51(2):87-90.

[28] Awad WI, Graves TD, White VC, et al. Airway obstruction complicating mediastinal tuberculosis: a life threatening presentation. Ann Thorac Surg 2002;74(1):261-3.

[29] Stephen T, Thankachen R, Parihar B, et al. Multilocular tuberculous cyst of thymus gland. J Thorac Cardiovasc Surg 2003;126(6):2093-4.

[30] Sacco O, Gambini C, Aicardi M, et al. Thymus tuberculosis poorly responding to anti-micobacterial therapy in a young girl with primary infection. Sarcoidosis Vasc Diffuse Lung Dis 2004;21(3):232-6.

[31] Kpodonu J, Cook JL, Massad MG, et al. Tuberculosis of the thymus: a case report and review of literature. Curr Respir Med Rev 2005;1(2):123-6.

[32] Saieg MT, Bernardi FC, Goncalves R, et al. Tuberculosis of thymus. J Bras Pneumol 2007;33(3):355-7.

[33] Iwata $\mathrm{T}$, Inoue $\mathrm{K}$, Mizuguchi $\mathrm{S}$, et al. Thymic tuberculosis preoperatively evaluated with Thallium201 SPECT: two resected cases. Ann Thorac Cardiovasc Surg 2007;13(1):44-6.

[34] Prabhu AD, Ismail ET, Rajendran S, et al. Tuberculosis of thymus-a case report. Heart Lung Circ 2008;17(4):345-6.

[35] Ganesan S, Ganesan K. Multilocular thymic tuberculosis: case report. $\mathrm{Br} \mathrm{J}$ Radiol 2008;81(964):e127-e9. 
[36] Ruangnapa K, Anuntaseree W, Suntornlohanakul S. Tuberculosis of the thymus in a 6-month old infant with literature review. Pediatr Infect Dis J 2014;33(2):210-2.

[37] Pillai KR, Prakash M, Pai MR. Clinicopathological characteristics of thymic tuberculosis-a rare entity. Journal of Clinical and Diagnostic Research JCDR 2016;10(9):ED13-ED15.
[38] Elamin WF, Hannan K. Pericardial cyst: an unusual cause of pneumonia. Cases J 2008;1(1):26. 